\title{
The seasonal appearance and chemical composition characteristics of cladode of Opuntia humifusa
}

\author{
Hee Jung Kim, Mi-Hyun Kim, Mi Jang, Tae-Gyu Lim, Hee-Do Hong, \\ Young Kyoung Rhee, Kyung-Tack Kim, Chang-Won Cho* \\ Traditional Food Research Center, Korea Food Research Institute, Seongnam 13539, Korea
}

\section{천년초 줄기의 수확 시기 별 외관 및 성분 품질 특성}

\author{
김희정 · 김미현 · 장미 · 임태규·홍희도·이영경 · 김경탁·조장원* \\ 한국식품연구원 전통식품연구센터
}

\begin{abstract}
The seasonal appearance and the chemical composition characteristics of cladode of Opuntia humifusa were investigated in this study. The minor (horizontal) and major (vertical) axes, the width, and weight of $O$. humifusa cladode were compared for its appearance features. Moisture, crude protein, ash, fat, color, dietary fiber, mineral, and amino acids contents were measured for the comparison of their chemical composition characteristics. The cladode of $O$. humifusa harvested in summer showed higher values of minor and major axis, width, and weight than those harvested in winter. According to the results of Hunter color index, cladode of $O$. humifusa harvested in summer showed the highest lightness level (Hunter $\mathrm{L}$ value). In the meanwhile, cladode of $O$. humifusa harvested in spring showed the highest Hunter a (redness) and b (yellowness) values. Cladode of $O$. humifusa harvested in summer had the lowest crude protein and crude fat contents, while it showed the highest crude ash content. The total contents of moisture and dietary fiber were significantly greater than summer-harvested cladode of $\boldsymbol{O}$. humifusa followed by spring- and winter-harvested cladode of $\boldsymbol{O}$. humifusa. The major mineral content of all seasonal cladode of $O$. humifusa was $\mathrm{Ca}^{2+}$. Glutamic acid and aspartic acid were the major amino acids in all seasonal samples. Contrary, the contents of total amino acids and free amino acids were the lowest in summer-harvested cladode of $\boldsymbol{O}$. humifusa. Taken together, it was concluded that the appearance and chemical quality of cladode of $\boldsymbol{O}$. humifusa was versatile depending on the harvesting season.
\end{abstract}

Key words : Opuntia humifusa, cladode, season, appearance, chemical composition.

\section{서 론}

선인장은 반 건조 사막지대에서 재배가 가능한 몇 안 되는 식물 중 하나로 여러 사막 국가에서 중요한 영양 급원 으로 인정받고 있다(1). 우리나라에서 재배되는 선인장 중 열매가 있고, 줄기가 손바닥 모양으로 생긴 Opuntia 속에

*Corresponding author. E-mail : cwcho@kfri.re.kr Phone : 82-31-780-9312, Fax : 82-31-709-9876

Received 11 February 2016; Revised 12 April 2016; Accepted 22 April 2016.

Copyright (c) The Korean Society of Food Preservation. All rights reserved.
속하는 선인장은 2종으로, 내륙지방의 천년초 선인장 (Opuntia humifusa)과 제주 지역의 백년초 선인장(Opuntia ficus-indica var. Saboten)으로 구분할 수 있다. 그 중 천년초 선인장은 내륙지방 중에서도 전라남도 신안, 충청남도 아 산 지방, 그 외 경기도 일부 지역에서 재배되고 있는 국내 토종 식용 선인장으로, 열대지방이 원산지인 백년초와 달 리 영하 $20^{\circ} \mathrm{C}$ 의 혹한에도 살아남으며 병충해에 강한 특징을 지니는 것으로 알려져 있다(2).

손바닥 선인장을 이용한 연구는 항산화(3), 항균(4), 항당 뇨(5), 항암활성 $(6,7)$ 등 기능성 및 생리활성에 관한 연구가 주를 이루고 있으며, 고지혈증(8)과 같은 대사성 질환에도 영향을 미치는 것으로 알려져 있다. 또한, 재배기술(9), 가시 
제거기(10), 돼지 사료(11)로의 개발 등의 연구가 이루어져 지역 특산물로의 활용방안이 모색되고 있다. 원산지인 멕 시코 등지에서는 손바닥 선인장을 과실작물로 인식하여 일상적으로 시장에서 흔히 구입이 가능하며 구입 후 일주일 정도 숙성하여 샐러드와 같은 요리나, 주스, 잼, 젤리 등으로 만들어 섭취하고 있다. 특히 껍질을 벗긴 줄기를 깍둑썰기 하거나 길게 잘라 물에 오래 끓인 것을 노팔, 노팔리토스 (nopalitos)라고 칭하며 통조림으로 가공하여 판매하고 있 다(1). 국내에서는 추출물과 음료, 초콜릿, 스낵, 국수, 차, 비누, 화장품 등의 가공제품이 개발되어 있다.

일반적으로 선인장은 잎의 형태를 가지고 있지 않으나, Opuntia 속의 선인장은 잎의 형태를 가지고 있다. 하지만 그 모양이 두꺼워 일반적인 잎과는 차이가 있으며, 계절적 으로 생겼다가 탈리가 쉽게 일어나는 것으로 알려져 있다 (12). 또한, 우리나라는 뚜렷한 사계절을 가지고 있어 계절 마다 생산되는 식재료의 종류가 다르고, 일 년 내내 생산되 더라도 계절에 따라 맛과 성분이 다른 특징을 가지고 있다 (13). 천년초 선인장의 경우 열매는 10 월경에만 수확 가능한 반면, 줄기는 연중 수확이 가능한 것으로 알려져 있어 수확 시기에 따른 외관의 변화나 영양성분의 차이에 대한 연구가 선행되어야 섭취나 가공, 저장, 조리방식에 있어 응용이 가 능할 것으로 생각되나 이에 대한 연구는 부족한 실정이다.

따라서 본 연구에서는 국내산 손바닥 천년초 선인장의 활용도를 높이기 위해 계절별로 다른 특성을 보이는 천년초 줄기 시료의 외관 및 이화학적 품질 특성을 비교, 조사하였다.

\section{재료 및 방법}

\section{실험 재료}

본 실험에 사용한 천년초(Opuntia humifusa)는 충남 아산 지역에 위치한 천년초 농장에서 재배한 것을 구입하여 사용 하였다. 본 연구에서 봄 천년초 줄기는 4 월, 여름은 8 월, 겨울은 12 월에 수확한 것으로 규정하여 분석에 사용하였 다. 생 시료를 세척, 자연건조 후 외관 특성을 측정하였으며, 외관 측정이 끝난 시료(계절별 100 개)를 세절 후 동결건조 하고 $60 \mathrm{mesh}$ 사이즈로 균일하게 분쇄한 후 desiccator에 보관하며 성분분석을 실시하였다.

\section{외관 특성}

천년초 줄기의 외관 특성은 생 시료를 대상으로 측정하 였으며, 매회 얻은 시료의 외형을 측정하였다. 중량은 전자 저울(CB-1200, CAS, Seongnam, Korea)을 이용하여 소수점 둘째 자리까지 나타내었고, 타원형인 시료의 가장 긴축을 장축(major axis), 가장 짧은 축을 단축(minor axis)으로 정하 여 $\mathrm{cm}$ 단위로 측정하였으며, 폭 측정에는 calliper(Absolute Digimatic CD-15CP, Mitutoyo Co., Kawasaki, Japan)를 사용
하여 $\mathrm{mm}$ 단위로 나타내었다.

\section{일반 성분 함량 측정}

동결건조 후 분쇄한 천년초 줄기 분말을 이용하여 성분 분석을 실시하였다. 일반성분 분석, 무기질 함량, 구성 아미 노산은 $\mathrm{AOAC}$ 법(14)에 준하여 수행하였다. 수분은 $105^{\circ} \mathrm{C}$ 상압가열건조법, 조지방은 soxhlet 추출법, 조회분은 직접 회화법, 조단백의 함량은 Kjeldahl법을 이용하였다. 탄수화 물은 100 에서 수분, 조단백, 조지방, 조회분 함량을 뺀 값으 로 하였다.

\section{색도 측정}

건조를 통해 얻어진 천년초 줄기 시료의 색도는 색차계 (Minolta CR-200, Konica minolta Co., Tokyo, Japan)를 이용 하여 측정하였다. 건조, 분쇄한 가루 형태의 시료를 무작위 로 10 회 반복 측정하여 명도(L, lightness), 적색도 $(\mathrm{a}$, redness), 황색도(b, yellowness)값으로 표시하였다. 색도 측 정 시 표준판은 $\mathrm{L}$ 값 $97.69, \mathrm{a}$ 값 $+0.37, \mathrm{~b}$ 값 +1.96 인 백색의 calibration plate를 표준으로 하여 측정하였다. 시료간의 색 도차이를 나타내는 delta $\mathrm{E}(\Delta \mathrm{E})$ 값은 다음의 식을 이용하여 계산하였다(15).

$$
\Delta E=\sqrt{\left(L_{1}-L_{2}\right)^{2}+\left(a_{1}-a_{2}\right)^{2}+\left(b_{1}-b_{2}\right)^{2}}
$$

\section{식이섬유 함량 측정}

천년초 줄기의 식이섬유 함량을 측정하기 위해 동결건조 후 분쇄한 시료를 $\mathrm{AOAC}$ 법(14)에 준하여 효소분해 하였으 며, 단백질과 회분의 함량을 함께 측정하여 총 식이섬유 함량을 정량하였다.

\section{유리 아미노산 함량 측정}

동결건조 후 분쇄한 천년초 줄기 분말 약 $1 \mathrm{~g}$ 을 $70 \%$ ethanol로 1시간 동안 초음파 추출(Bransonic 5510E-DTH, Branson ultrasonics corporation, Danbury, CT, USA)한 후 다시 실온에서 24시간 추출하였으며, $0.2 \mu \mathrm{m}$ 여과용 필터 (Whatman, GE Healthcare Life Sciences Co., Buckinghamshire, $\mathrm{UK}$ )를 이용하여 여과한 후 HPLC용 시료로 사용하였다. 분석 장치는 Dionex Ultimate 3000(Thermo Fisher Scientific Co., Waltham, MA, USA)이며, UV Detector를 이용해 338 $\mathrm{nm}$ 에서 분석하였다.

\section{통계분석}

천년초 줄기의 계절별 성분분석 결과에 대한 통계처리는 IBM SPSS Statistics(Ver 22.0, IBM Corp., Armonk, NY, USA)를 이용하여 측정하였고, 유의성 검증을 위해 ANOVA 분산분석 및 Duncan's multiple range test를 실시하 였다. 


\section{결과 및 고찰}

\section{천년초 줄기의 외관 특성}

천년초 줄기는 일정하지 않은 형태를 보이므로 외형적 특성을 측정하기 위하여 타원형의 축 중 가장 긴축을 장축 으로, 가장 짧은 축을 단축으로 정해 크기를 측정하였다. 겨울 천년초 줄기의 외형은 단축이 $2.9 \sim 7.6 \mathrm{~cm}$ 범위로 나타 났으며, 장축이 $3.2 \sim 12.0 \mathrm{~cm}$, 폭은 $5.52 ~ 9.66 \mathrm{~mm}$, 중량은 $4.1 \sim 6.7 \mathrm{~g}$ 범위로 나타나 크기가 가장 작고 중량의 편차는 비교적 큰 것으로 조사되었다. 반면 여름 천년초 줄기의 외형은 단축이 $4.2 ~ 8.4 \mathrm{~cm}$ 범위로 나타났으며, 장축이 $5.3 \sim 17.5 \mathrm{~cm}$, 폭은 5.52 11.14 mm, 중량은 $11.1 \sim 76.9 \mathrm{~g}$ 범위 로 나타나 겨울 시료에 비해 크기와 중량이 매우 증가한 것을 확인할 수 있었다(Table 1). 평균적으로 각 계절 시료의 단축 대비 장축의 비를 계산하면 겨울은 1.39 , 봄 1.67 , 여름 이 1.71 로 나타나 겨울에서 여름 시료로 갈수록 장축의 길이 가 점차 늘어나며, 겨울로 갈수록 장축이 줄어드는 것을 확인하였다. 이는 Fig. 1 의 외관으로도 쉽게 확인이 가능하 다.

Table 1. Appearance features of seasonal Opuntia humifusa cladodes

\begin{tabular}{crrrrrr}
\hline & \multicolumn{3}{c}{ Summer $(\mathrm{n}=82)$} & \multicolumn{3}{c}{ Winter $(\mathrm{n}=100)$} \\
\cline { 2 - 7 } & Max. & Mean & Min. & Max. & Mean & Min. \\
\hline Minor axis $(\mathrm{cm})$ & 8.40 & 6.41 & 4.20 & 7.60 & 5.05 & 2.50 \\
Major axis $(\mathrm{cm})$ & 17.50 & 10.98 & 5.30 & 12.00 & 7.04 & 3.20 \\
Width $(\mathrm{mm})$ & 11.14 & 8.59 & 5.52 & 9.66 & 7.63 & 5.52 \\
Weight $(\mathrm{g})$ & 76.90 & 40.51 & 11.10 & 46.70 & 18.72 & 4.10 \\
\hline
\end{tabular}

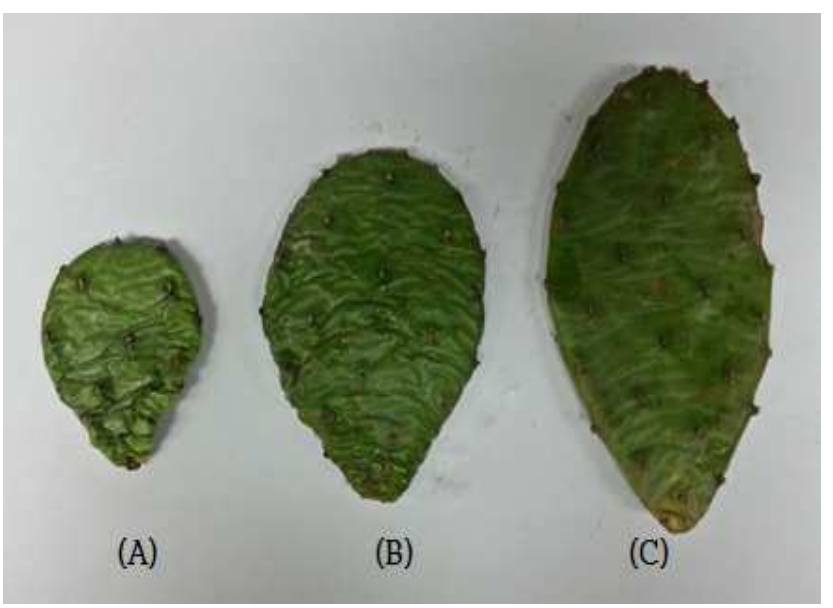

Fig. 1. The photos of seasonal Opuntia humifusa cladodes.

A, Winter; B, Spring; C, Summer cladode sample.

Fig. 2에서 각 시료들의 분포를 살펴보면 개별 선인장의 크기나 모양이 정규 분포에 가까운 형상을 보이기는 하나 매우 분산되어 있고, 여름과 겨울 시료의 외형이 변화한다
는 점을 확인할 수 있다. 단축의 경우 여름 천년초 줄기와 겨울 시료가 다수의 분포를 보인 지점이 서로 $2 \mathrm{~cm}$ 가량 차이가 났고, 장축의 경우 $4 \mathrm{~cm}$ 가량으로 그 차이가 더욱 벌어지는 점을 확인할 수 있었다. 중량의 경우에는 여름 시료의 평균값이 겨울 시료의 2 배 이상으로 나타나 차이가 매우 큰 것으로 나타났다.

\section{천년초 줄기의 일반 성분 함량}

수확 후 건조를 하지 않은 천년초 생 시료의 총 수분함량 은 여름 시료가 $86.86 \%$ 로 유의적으로 가장 높은 값을 보였 다(Table 2). 또한, 봄 시료는 $81.07 \%$, 겨울 시료는 $75.57 \%$ 로 유의적 수준에서 차이를 보이며 계절의 변화에 따라 생 시료의 수분함량이 점차 감소하는 것을 확인할 수 있었다.

천년초 줄기의 계절에 따른 일반 성분을 분석한 결과는 Table 3에 나타내었다. 일반성분분석의 경우 동결건조 된 분말을 대상으로 수행하였다. 동결건조물의 수분, 조단백, 탄수화물 함량은 모든 시료가 유의적인 차이를 보였다. 동 결건조물의 수분함량은 봄 시료가 가장 높게 나타났다. 조 회분의 경우 봄과 겨울의 시료는 유의차가 나타나지 않았 고, 여름 시료만이 $9.11 \%$ 로 유의적으로 가장 높은 함량을 보였다. 조지방의 경우에도 역시 봄과 겨울의 시료는 유의 차가 나타나지 않았고, 여름 시료는 $0.19 \%$ 로 유의적으로 가장 적은 함량을 보였다. Jung 등(2)의 연구에서 천년초 줄기를 11 월에 생산한 것으로 측정하였을 때, 조단백 $5.43 \%$, 조지방 $1.69 \%$, 조회분 $12.40 \%$ 로 보고하여 조회분을 제외한 항목에서 본 연구의 봄, 겨울의 시료 결과와 유사한 함량을 보였다. 멕시코의 야생 Opuntia 속 선인장과 시판 제품의 일반성분을 분석한 연구(16)에 따르면, 조지방은 $0.1 \sim 1.8 \%$ 로 매우 낮아 본 연구 결과와 유사했고, 조단백은 $6.7 \sim 19.0 \%$, 조회분은 $5.2 ~ 19.7 \%$ 으로 편차는 컸으나 같은 속의 선인장이 유사한 일반성분 구성을 나타낸다는 점을 확인할 수 있었다.

Table 2. Total moisture content of seasonal Opuntia humifusa cladodes

\begin{tabular}{cccc} 
& & & (unit: \%) \\
\hline Total moisture & Spring & Summer & Winter \\
\hline
\end{tabular}

${ }^{1)}$ All results are expressed as mean \pm SD for three replicates.

${ }^{2)}$ Different superscripts in the same row are significantly different at $p<0.05$ by Duncan's multiple range test.

색 도

천년초 줄기의 색도를 측정한 결과는 Table 4에 나타내었 다. 측정결과 $\mathrm{L}$ 값은 여름시료가 유의적으로 가장 높게 나타 났다. Ozkan 등(17)의 연구에서 살구를 이용해 실험했을 때 건조 후 재수화하며 수분함량이 증가할수록 $\mathrm{L}$ 값과 $\mathrm{b}$ 값 이 증가하는 반면 a값은 감소하는 것으로 나타났다. 이를 


\section{Summer}
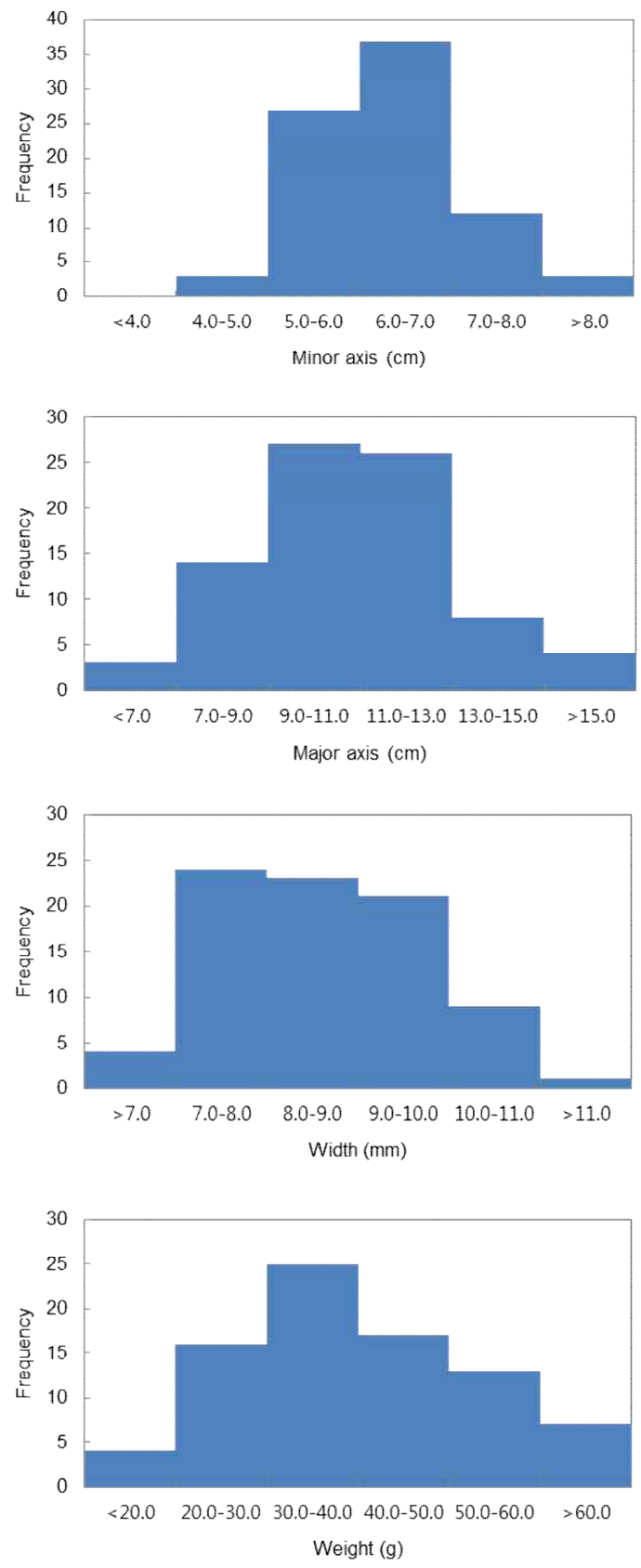

\section{Winter}
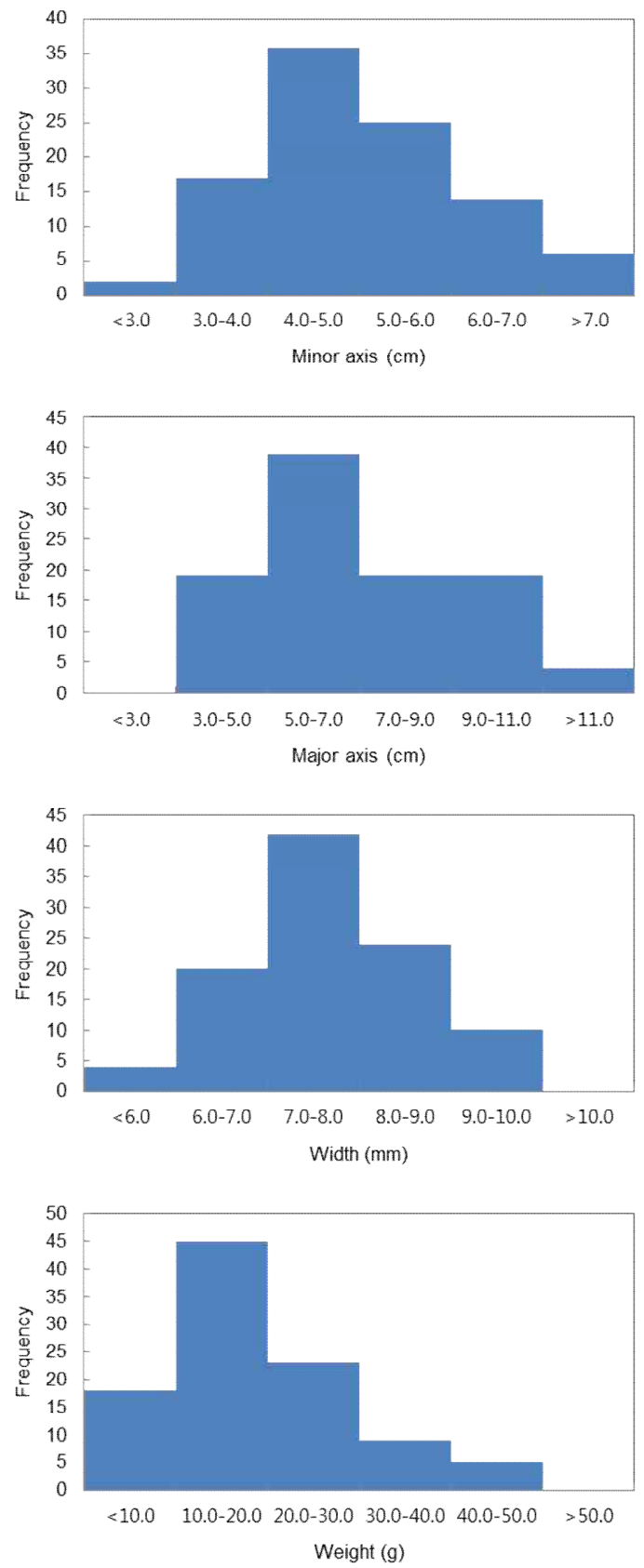

Fig. 2. Interval distribution of appearance features of Opuntia humifusa cladodes in different season.

이용한 상관관계 분석을 통해 살구의 수분함량과 색도의 관계를 추측한 바 있으며, 이것은 건조에 따른 색소, 화학적 변화가 색도에 영향을 미친다는 점을 시사한다고 밝혔다. 선인장의 수분함량 및 색도의 상관관계는 연구된 바 없으 나, 선인장의 수분함량과 건조 정도에 따라 색도가 차이를 보일 가능성을 발견하였다. 또한, 본 연구에서 계절에 따라 생 시료의 수분함량에 큰 차이가 난다는 점을 확인하였으므 로, 선인장의 건조에 따른 색도의 변화에 대한 추가적인 연구가 필요할 것으로 사료된다. 본 연구에서 $\mathrm{a}, \mathrm{b}$ 값은
봄 시료가 유의적으로 높게 나타났다. 계절별 시료간의 $\Delta \mathrm{E}$ 값을 비교하였을 때 봄 시료와 여름 시료간의 $\Delta \mathrm{E}$ 는 6.55 , 여름 시료와 겨울 시료간의 $\Delta \mathrm{E}$ 는 4.21 , 겨울 시료와 봄 시료 간의 $\Delta \mathrm{E}$ 는 5.35 로 봄 시료와 여름 시료간의 색도 차이가 가장 큰 것으로 나타났다.

\section{식이섬유 함량}

천년초 줄기의 계절에 따른 식이섬유 함량을 조사한 결 과는 Table 5 와 같다. 제주 백년초 선인장과 알로에 성분을 
Table 3. Chemical compositions of seasonal Opuntia humifusa cladodes

\begin{tabular}{|c|c|c|c|}
\hline & Spring & Summer & Winter \\
\hline Moisture & $0.40 \pm 0.04^{1) 22)}$ & $0.11 \pm 0.05^{b}$ & $0.04 \pm 0.01^{c}$ \\
\hline Crude protein & $6.54 \pm 0.03^{\mathrm{a}}$ & $3.90 \pm 0.00^{\mathrm{c}}$ & $6.04 \pm 0.02^{b}$ \\
\hline Crude ash & $8.89 \pm 0.08^{b}$ & $9.11 \pm 0.09^{\mathrm{a}}$ & $8.93 \pm 0.03^{b}$ \\
\hline Crude fat & $1.57 \pm 0.04^{\mathrm{a}}$ & $0.19 \pm 0.06^{b}$ & $1.56 \pm 0.01^{\mathrm{a}}$ \\
\hline Carbohydrate & $82.64 \pm 0.22^{\mathrm{c}}$ & $86.68 \pm 0.09^{\mathrm{a}}$ & $83.46 \pm 0.05^{b}$ \\
\hline
\end{tabular}

${ }^{1)}$ All results are expressed as mean \pm SD for three replicates.

${ }^{2)}$ Different superscripts in the same row are significantly different at $\mathrm{p}<0.05$ by Duncan's multiple range test.

Table 4. Hunter's color values of seasonal Opuntia humifusa cladodes

\begin{tabular}{cccc}
\hline & Spring & Summer & Winter \\
\hline L & $68.14 \pm 1.15^{1)(2)}$ & $73.20 \pm 0.71^{\mathrm{a}}$ & $72.29 \pm 0.92^{\mathrm{b}}$ \\
$\mathrm{a}$ & $-7.49 \pm 0.13^{\mathrm{a}}$ & $-11.51 \pm 0.26^{\mathrm{c}}$ & $-8.06 \pm 0.18^{\mathrm{b}}$ \\
$\mathrm{b}$ & $23.91 \pm 0.83^{\mathrm{a}}$ & $22.83 \pm 0.49^{\mathrm{b}}$ & $20.59 \pm 0.53^{\mathrm{c}}$ \\
\hline
\end{tabular}

${ }^{1)}$ All results are expressed as mean \pm SD for three replicates.

Different superscripts in the same row are significantly different at $p<0.05$ by Duncan's multiple range test.

Table 5. Dietary fiber content of seasonal Opuntia humifusa cladodes

(unit: \%)

\begin{tabular}{|c|c|c|c|}
\hline & Spring & Summer & Winter \\
\hline Dietary fiber & $60.41 \pm 0.75^{1162)}$ & $67.18 \pm 0.35^{\mathrm{a}}$ & $58.77 \pm 0.20^{c}$ \\
\hline
\end{tabular}

비교한 연구(18)에서는 선인장 줄기의 식이섬유 함량을 $33.2 \%$ 로 보고하여 알로에의 함량(31.0\%)보다도 높은 것은 물론, 과일류(0.19 2.91\%), 채소류(0.99 7.42\%)보다 월등 히 높으며 해조류(28.70 38.19\%)와 비슷한 수준이라고 밝 힌 바 있다. 본 연구의 천년초 줄기 식이섬유 함량은 이보다 높은 수준(58.77 67.18\%)으로 확인되어 식이섬유의 함량 이 매우 높은 식품임을 확인하였다.

\section{무기질 함량}

천년초 줄기의 계절에 따른 무기질 함량으로 $\mathrm{Ca}, \mathrm{Fe}, \mathrm{K}$, $\mathrm{Mg}, \mathrm{Na}, \mathrm{P}$ 을 측정한 결과는 Table 6과 같다. 칼슘함량은 겨울 시료가 4,745.09 $\mathrm{mg} \%$ 로 유의적으로 높았다. Jung 등 (2)의 연구에서 11 월에 수확한 천년초 줄기의 칼슘 함량을 $3,671.79 \mathrm{mg} \%$ 로 보고하였는데, 본 연구의 겨울 천년초 줄 기보다는 함량이 낮고 봄 천년초 줄기보다는 높았다. 철, 마그네슘, 나트륨의 함량은 여름 시료가 가장 높았고, 칼륨
은 봄 시료, 인은 겨울 시료가 가장 높아 일정한 경향성은 발견할 수 없었으나, 모두 유의적인 수준에서 함량 차이를 보여 계절에 따라 시료의 무기질 함량에서 차이가 난다는 점을 확인하였다.

한국인이 주로 먹는 과일, 채소의 사계절에 따른 무기질 함량의 변화를 살펴본 Kim 등(13)의 연구에서는 나트륨의 경우 사과에는 봄, 여름, 겨울에 비해 가을에 가장 많이 함유되어있으나, 반면 귤에는 가을에 가장 적은 등 식품마 다 계절의 변화에 따라 수분함량, 고형물 함량의 차이와 함께 무기질의 차이가 있다고 밝힌 바 있어 계절에 따라 채취한 천년초 줄기가 계절과일과 같은 경향성을 보이는 것으로 나타났다.

Table 6. Mineral contents of seasonal Opuntia humifusa cladodes

\begin{tabular}{cccc} 
& & & (unit: mg\%) \\
\hline & Spring & Summer & Winter \\
\hline $\mathrm{Ca}$ & $3248.22 \pm 67.84^{1)(2)}$ & $3678.74 \pm 45.51^{\mathrm{b}}$ & $4745.09 \pm 82.89^{\mathrm{a}}$ \\
$\mathrm{Fe}$ & $5.47 \pm 0.02^{\mathrm{c}}$ & $17.50 \pm 1.23^{\mathrm{a}}$ & $8.78 \pm 0.23^{\mathrm{b}}$ \\
$\mathrm{K}$ & $1364.34 \pm 33.57^{\mathrm{a}}$ & $777.75 \pm 2.40^{\mathrm{c}}$ & $1224.79 \pm 41.11^{\mathrm{b}}$ \\
$\mathrm{Mg}$ & $783.67 \pm 21.97^{\mathrm{b}}$ & $1149.77 \pm 9.03^{\mathrm{a}}$ & $738.02 \pm 8.99^{\mathrm{b}}$ \\
$\mathrm{Na}$ & $12.02 \pm 0.36^{\mathrm{b}}$ & $15.68 \pm 0.37^{\mathrm{a}}$ & $4.73 \pm 0.05^{\mathrm{c}}$ \\
$\mathrm{P}$ & $262.79 \pm 4.42^{\mathrm{b}}$ & $210.37 \pm 1.09^{\mathrm{c}}$ & $281.46 \pm 3.10^{\mathrm{a}}$ \\
\hline
\end{tabular}

${ }^{1)}$ All results are expressed as mean \pm SD for three replicates.

${ }^{2}$ Different superscripts in the same row are significantly different at $p<0.05$ by Duncan's multiple range test.

\section{아미노산 함량}

천년초 줄기의 계절에 따른 구성 아미노산 함량을 조사 한 결과는 Table 7과 같다. 전체 아미노산의 양은 여름 천년 초 줄기가 $3,386.36 \mathrm{mg} \%$ 로 가장 적었고, 봄 천년초 줄기가 $5,463.86 \mathrm{mg} \%$ 으로 가장 많았으며 모든 시료에서 glutamic acid, aspartic acid의 함량이 가장 높았다. Jung 등(2)의 연구 에서 11월에 수확한 천년초 줄기의 구성 아미노산 함량을 조사한 결과와 비교했을 때, glutamic acid, aspartic acid의 함량이 가장 높았고, 두 아미노산이 차지하는 비율은 전체 구성 아미노산의 $25.43 \%$ 였다. Cho 등(19)의 연구에서 신안 지역의 백년초를 이용하여 구성 아미노산을 측정한 결과에 서도 glutamic acid가 가장 높은 것으로 나타나 glutamic $\mathrm{acid}$ 가 손바닥 선인장의 대표 아미노산인 것으로 추측되었 다. 여름 천년초 줄기의 경우 특징적으로 alanine 수치가 전체 아미노산 양이 적음에도 다른 시료에 비해 오히려 높았다.

천년초 줄기의 계절에 따른 유리 아미노산 함량을 조사 한 결과는 Table 8 과 같다. 유리된 아미노산의 경우 모든 시료의 특성이 달랐는데, 봄 천년초 줄기의 경우 glutamine, proline, $\mathrm{y}$-aminobutyric acid(GABA), aspartic acid의 순으로 함량이 높았다. 겨울 천년초 줄기는 GABA, glutamine, 
Table 7. Total amino acids of seasonal Opuntia humifusa cladodes

\begin{tabular}{|c|c|c|c|}
\hline & Spring & Summer & Winter \\
\hline Aspartic acid & $726.84 \pm 7.14^{\left.1 / 2)^{2}\right)}$ & $433.08 \pm 8.53^{b}$ & $724.79 \pm 0.64^{a}$ \\
\hline Threonine & $277.54 \pm 4.48^{\mathrm{a}}$ & $175.80 \pm 0.86^{\mathrm{c}}$ & $243.70 \pm 0.11^{b}$ \\
\hline Serine & $274.22 \pm 2.99^{\mathrm{b}}$ & $180.05 \pm 2.29^{c}$ & $295.49 \pm 0.62^{\mathrm{a}}$ \\
\hline Glutamic acid & $1,054.23 \pm 6.99^{\mathrm{a}}$ & $543.74 \pm 26.02^{\mathrm{c}}$ & $803.59 \pm 0.61^{b}$ \\
\hline Proline & $406.90 \pm 14.68^{\mathrm{a}}$ & $164.20 \pm 5.67^{b}$ & $410.57 \pm 1.69^{\mathrm{a}}$ \\
\hline Glycine & $288.96 \pm 2.72^{\mathrm{a}}$ & $198.78 \pm 5.32^{c}$ & $263.78 \pm 0.26^{b}$ \\
\hline Alanine & $326.87 \pm 0.56^{\mathrm{a}}$ & $338.02 \pm 8.79^{\mathrm{a}}$ & $285.87 \pm 0.11^{\mathrm{b}}$ \\
\hline Valine & $249.49 \pm 3.03^{\mathrm{a}}$ & $157.93 \pm 3.43^{\mathrm{b}}$ & $251.65 \pm 0.20^{\mathrm{a}}$ \\
\hline Methionine & $60.60 \pm 0.72^{\mathrm{a}}$ & $39.34 \pm 1.37^{b}$ & $54.97 \pm 5.57^{\mathrm{a}}$ \\
\hline Isoleucine & $211.87 \pm 9.01^{\mathrm{a}}$ & $141.69 \pm 1.64^{c}$ & $179.05 \pm 0.42^{\mathrm{b}}$ \\
\hline Leucine & $443.57 \pm 6.64^{\mathrm{a}}$ & $297.56 \pm 1.34^{c}$ & $380.64 \pm 1.06^{b}$ \\
\hline Tyrosine & $170.68 \pm 3.56^{\mathrm{a}}$ & $103.55 \pm 5.29^{\mathrm{b}}$ & $100.08 \pm 2.25^{\mathrm{b}}$ \\
\hline Phenylalanine & $238.73 \pm 12.04^{\mathrm{a}}$ & $134.70 \pm 6.50^{b}$ & $222.81 \pm 4.59^{\mathrm{a}}$ \\
\hline Lysine & $391.19 \pm 6.67^{\mathrm{a}}$ & $278.38 \pm 2.74^{b}$ & $402.74 \pm 11.55^{\mathrm{a}}$ \\
\hline Histidine & $105.81 \pm 1.02^{\mathrm{b}}$ & $49.68 \pm 1.05^{\mathrm{c}}$ & $115.39 \pm 0.38^{\mathrm{a}}$ \\
\hline Arginine & $236.38 \pm 3.91^{\mathrm{a}}$ & $149.86 \pm 1.53^{c}$ & $213.89 \pm 0.89^{b}$ \\
\hline $\mathrm{TAA}^{3)}$ & $5,463.86$ & $3,386.36$ & $4,949.00$ \\
\hline $\mathrm{EAA}^{4)}$ & $1,978.79$ & $1,275.08$ & $1,850.94$ \\
\hline EAA/TAA (\%) & 36.22 & 37.65 & 37.40 \\
\hline \multicolumn{4}{|c|}{$\begin{array}{l}\text { 1) All results are expressed as mean } \pm \text { SD for three replicates. } \\
\text { Different superscripts in the same row are significantly different at } \mathrm{p}<0.05 \text { by } \\
\text { Duncan's multiple range test. } \\
\text { Total amino acid. } \\
\text { Total essential amino acid. }\end{array}$} \\
\hline
\end{tabular}

proline, aspartic acid의 순으로 나타나 순서에 약간의 차이 는 있었지만 다량 함유된 유리 아미노산의 구성이 유사하였 으며, 그 양 또한 비슷한 수준이었다. 여름 천년초 줄기의 경우에는 전체 아미노산의 양이 매우 적어 봄, 겨울과 차이 를 보였으나, 총량 대비 필수 아미노산의 비중이 상대적으 로 높았다. GABA는 일반적으로 발아된 곡류에 많이 함유 되어 있다고 알려져 있으며 현미의 경우 2 6 $\mathrm{mg} \%$, 발아현 미는 10 13.5 mg\%, 품종별 발아보리는 $14.3 \sim 20.9 \mathrm{mg} \%$ 의 함량이 보고된 바 있어(20), 천년초 특히 겨울 천년초의 경우 $220.8 \mathrm{mg} \%$ 로 상당히 높은 $\mathrm{GABA}$ 함량을 가지는 것으 로 확인되었다. 비단백질 구성 아미노산인 $\mathrm{GABA}$ 는 뇌에서 억제성 신경전달물질로 작용하며 혈압 저하, 신경 안정, 이뇨 작용 등에 효과가 있는 것으로 알려져 있다(21). 따라 서 천년초 줄기의 경우 $\mathrm{GABA}$ 함량이 높은 기능성 식품으로 개발이 가능할 것으로 사료되었다. Taurine의 경우 봄과 여름 천년초 줄기에서는 검출되지 않았으나 겨울 천년초 줄기에서 소량이나마 발견되어 특징적이었다. 이상의 연구
결과를 통해 천년초 줄기가 계절에 따라 외관적인 특성뿐만 아니라 구성성분에 있어서도 변화를 보인다는 점을 확인할 수 있었다.

Table 8. Free amino acids of seasonal Opuntia humifusa cladodes

\begin{tabular}{|c|c|c|c|}
\hline & Spring & Summer & Winter \\
\hline Aspartic acid & $97.05 \pm 2.09^{1 / 62)}$ & $24.37 \pm 0.35^{c}$ & $108.81 \pm 1.17^{\mathrm{a}}$ \\
\hline Glutamic acid & $16.84 \pm 0.36^{\mathrm{a}}$ & $16.14 \pm 0.20^{\mathrm{a}}$ & $5.92 \pm 0.12^{b}$ \\
\hline Asparagine & $23.95 \pm 0.50^{c}$ & $4.94 \pm 0.02^{b}$ & $32.34 \pm 0.21^{\mathrm{a}}$ \\
\hline Serine & $50.11 \pm 0.54^{b}$ & $12.81 \pm 0.01^{\mathrm{c}}$ & $82.19 \pm 0.65^{\mathrm{a}}$ \\
\hline Glutamine & $170.00 \pm 1.27^{b}$ & $34.07 \pm 0.06^{c}$ & $220.57 \pm 1.24^{\mathrm{a}}$ \\
\hline Histidine & $5.71 \pm 0.21^{b}$ & $1.95 \pm 0.29^{c}$ & $8.14 \pm 0.11^{a}$ \\
\hline Glycine & $21.06 \pm 0.17^{\mathrm{b}}$ & $2.95 \pm 0.02^{\mathrm{c}}$ & $28.73 \pm 0.51^{\mathrm{a}}$ \\
\hline Threonine & $57.06 \pm 0.28^{\mathrm{a}}$ & $13.06 \pm 0.05^{\mathrm{c}}$ & $46.27 \pm 0.90^{b}$ \\
\hline Arginine & $29.83 \pm 0.66^{b}$ & $6.04 \pm 0.23^{\mathrm{c}}$ & $32.58 \pm 0.28^{\mathrm{a}}$ \\
\hline Alanine & $50.32 \pm 0.60^{b}$ & $11.62 \pm 0.07^{c}$ & $58.55 \pm 0.46^{\mathrm{a}}$ \\
\hline Taurine & $\mathrm{ND}^{3)}$ & $\mathrm{ND}$ & $1.17 \pm 0.00$ \\
\hline $\begin{array}{c}\gamma \text {-aminobutyric } \\
\text { acid }\end{array}$ & $124.91 \pm 2.04^{b}$ & $25.13 \pm 0.01^{\mathrm{c}}$ & $220.78 \pm 2.63^{\mathrm{a}}$ \\
\hline Tyrosine & $37.70 \pm 0.66^{b}$ & $7.75 \pm 0.12^{c}$ & $41.92 \pm 0.41^{\mathrm{a}}$ \\
\hline Valine & $52.77 \pm 1.01^{\mathrm{b}}$ & $20.18 \pm 0.04^{\mathrm{c}}$ & $73.86 \pm 0.20^{\mathrm{a}}$ \\
\hline Methionine & $0.46 \pm 0.14^{b}$ & $0.30 \pm 0.08^{b}$ & $28.18 \pm 0.21^{\mathrm{a}}$ \\
\hline Tryptophane & $7.12 \pm 0.89^{b}$ & $2.81 \pm 0.15^{c}$ & $30.34 \pm 0.41^{\mathrm{a}}$ \\
\hline Phenylalanine & $45.88 \pm 1.16^{b}$ & $12.31 \pm 0.10^{c}$ & $55.83 \pm 0.70^{\mathrm{a}}$ \\
\hline Isoleucine & $26.41 \pm 0.64^{b}$ & $7.91 \pm 0.08^{\mathrm{c}}$ & $44.31 \pm 0.83^{\mathrm{a}}$ \\
\hline Leucine & $77.22 \pm 1.52^{b}$ & $15.31 \pm 0.21^{\mathrm{c}}$ & $84.70 \pm 0.49^{\mathrm{a}}$ \\
\hline Lysine & $27.37 \pm 0.66^{\mathrm{a}}$ & $6.78 \pm 0.22^{c}$ & $22.29 \pm 0.03^{\mathrm{b}}$ \\
\hline Proline & $126.17 \pm 4.01^{b}$ & $11.68 \pm 0.13^{\mathrm{c}}$ & $212.36 \pm 7.75^{\mathrm{a}}$ \\
\hline $\mathrm{TAA}^{4)}$ & $1,047.94$ & 238.12 & $1,439.85$ \\
\hline $\mathrm{EAA}^{5)}$ & 292.87 & 77.81 & 363.58 \\
\hline EAA/TAA (\%) & 27.95 & 32.68 & 25.25 \\
\hline
\end{tabular}

${ }^{11}$ All results are expressed as mean \pm SD for three replicates.

${ }^{2)}$ Different superscripts in the same row are significantly different at $\mathrm{p}<0.05$ by Duncan's multiple range test.

${ }^{3)} \mathrm{ND}$, Not detected.

${ }^{4)}$ Total free amino acid.

${ }^{5}$ Total essential amino acid.

\section{요 약}

본 연구에서는 우리나라 토종 선인장인 천년초(Opuntia humifusa)의 줄기를 계절에 따라 채취하여 외관 및 성분을 비교하였다. 계절별 시료 간 외형을 장축, 단축, 폭, 중량의 항목으로 구분하여 측정, 비교하였으며, 색도를 측정하여 외관을 비교하였다. 외형은 겨울 천년초 줄기가 여름 천년 초 줄기에 비해 작았고, 단축 대비 장축의 비가 겨울 1.39 , 
봄 1.67 , 여름 1.71 순으로 나타났다. 중량 또한 여름 천년초 줄기가 평균 $40.51 \mathrm{~g}$ 으로 가장 무거웠다. 건조를 하지 않은 천년초 줄기 생시료의 수분함량은 여름 천년초 줄기가 $86.86 \%$ 로 가장 높았고, 유의수준에서 봄, 겨울 순으로 수분 함량이 줄어드는 경향을 나타냈다. 색도의 경우 $\mathrm{L}$ 값은 여름 천년초 줄기가 73.20으로 유의적 수준에서 가장 높았으며, $\mathrm{a}$ 값과 $\mathrm{b}$ 값은 봄 천년초 줄기가 가장 높았다. 일반성분의 함량은 여름 천년초 줄기가 조단백과 조지방이 유의적으로 가장 낮고 조회분의 경우 유의적으로 가장 높아 타 계절의 시료와 차이를 보였다. 식이섬유 함량 또한 여름 천년초 줄기가 $67.18 \%$ 로 가장 높았고, 봄, 겨울 순으로 유의적인 차이를 보였으며, 그 함량이 알로에와 같은 특용작물이나 과일, 채소류, 해조류보다 높은 수준으로 나타났다. 무기질 함량은 칼슘이 $4,745.09 \mathrm{mg} \%$ 로 가장 높았고, 모든 시료가 각 항목에서 유의적으로 계절에 따른 시료의 무기질 함량 차이를 보였다. 구성아미노산의 함량은 전체 합이 여름 천 년초 줄기가 $3,386.36 \mathrm{mg} \%$ 로 가장 적었고, 봄 천년초 줄기 가 $5,463.86 \mathrm{mg} \%$ 로 가장 높았다. 모든 시료에서 glutamic acid, aspartic acid의 함량이 가장 높은 특징을 보였다. 유리 아미노산 또한 시료 간에 다량 함유된 유리 아미노산의 구성이 유사하였고, 구성아미노산과 유사하게 여름 천년초 줄기의 총 함량이 가장 적어 봄, 겨울의 시료와 차이가 있었 다. 본 연구결과 연중 수확이 가능한 천년초의 줄기가 계절 에 따라 외관특성 및 성분에 차이를 보이는 것을 확인할 수 있었다. 계절에 따른 천년초 선인장 줄기의 외관특성은 생 천년초 줄기를 이용한 최소가공 제품류의 생산 시 고려 될 수 있을 것으로 판단되며, 성분특성의 경우 기능성 식품 을 포함한 가공제품의 제조 시 계절별로 차이를 나타내는 기능성분(식이섬유, GABA 등) 함량을 고려할 필요성이 있을 것으로 사료되었다.

\section{감사의 글}

본 연구는 농림축산식품부 고부가가치 식품기술개발사 업에 의해 이루어진 것으로 연구비 지원에 감사드립니다.

\section{References}

1. Saenz C (2000) Processing technologies an alternative for cactus pear (Opuntia spp.) fruits and cladodes. J Arid Environ, 46, 209-225

2. Jung BM, Han KA, Shin TS (2011) Food components of different parts of Cheonnyuncho (Opuntia humifusa) harvested from Yeosu, Jeonnam in Korea. J Korean Soc Food Sci Nutr, 40, 1271-1278
3. Lee KS, Oh CS, Lee KY (2005) Antioxidative effect of the fractions extracted from a cactus Cheonnyuncho (Opuntia humifusa). Korean J Food Sci Technol, 37, 474-478

4. Yoon MS, Yoo JS, Lee KK, Kim MK (2012) A study on biological activities of Opuntia humifusa cladode extracts. J Appl Biol Chem, 55, 117-121

5. Park CM, Kwak BH, Sharma BR, Rhyu DY (2012) Anti-diabetic effect of Opuntia humifusa stem extract. Kor J Pharmacogn, 43, 308-315

6. Jung BM, Shin MO, Kim HR (2012) The effects of antimicrobial, antioxidant, and anticancer properties of Opuntia humifusa stems. J Korean Soc Food Sci Nutr, 41, 20-25

7. Yoon JA, Hahm SW, Park JE, Son YS (2009) Total polyphenol and flavonoid of fruit extract of Opuntia humifusa and its inhibitory effect on the growth of MCF-7 human breast cancer cells. J Korean Soc Food Sci Nutr, 38, 1679-1684

8. Choi JC, Lee CK, Moon YI, Park HJ, Han YN (2002) Biological activities of the extracts from fruit and stem of prickly pear (Opuntia ficus-indica var. saboten) III. - Effects on subacute alcoholic hyperlipidemia in rats. Kor J Pharmacogn, 33, 238-244

9. Han YN (1999) Development of functional foods using fruit and stem of Opuntia ficus-indica var. saboten and characterization of their physiologically active constituents, Final Report of MAFRA

10. Moon YI (2000) Device for removing a thorn of a palm cactus fruit. Korea Patent No. 20-2000-0008357

11. Kim WI (2003) Development of pig feed using Opuntia ficus-indica L. var. saboten meal. Final Report of RDA, GOVP1200613236

12. Lee YH (2013) Growing cactus. Rural Development Administration, Jeonju, Korea, p 12-13

13. Kim JH, Kim MJ, Oh HK, Chang MJ, Kim SH (2007) Seasonal variation of mineral nutrients in Korean common fruits and vegetables. J East Asian Soc Dietary Life, $17,860-875$

14. AOAC (1996) Official Methods of Analysis. 15th ed, The Association of Official Analytical Chemistry, Washington DC, USA

15. Oliveira AC, Balaban MO (2006) Comparison of a colorimeter with a machine vision system in measuring color of gulf of mexico sturgeon fillets, Appl Eng Agric, 22, 583-588

16. Guevara-Figueroa T, Jimenez-Islas H, Reyes-Escogido 
ML, Mortensen AG, Laursen BB, Lin LW, Leon-Rodriguez AD, Fomsgaard IS, Barba de la Rosa AP (2010) Proximate composition, phenolic acids, and flavonoids characterization of commercial and wild nopal (Opuntia spp.). J Food Comp Anal, 23, 525-532

17. Ozkan M, Kirca A, Cemeroglu B (2003) Effect of moisture content on CIE color values in dried apricots. Eur Food Res Technol, 216, 217-219

18. Lee YC, Hwang KH, Han DH, Kim SD (1997) Compositions of Opuntia ficus-indica. Korean J Food Sci Technol, 29, 847-853
19. Cho IK, Jin SW, Kim YD (2009) Analysis of components in the parts of Opuntia ficus indica from Shinan Korea. Korean J Food Preserv, 16, 742-746

20. Na HS, Kim JY, Park HJ, Choi GC, Yang SI, Lee JH (2013) Comparison of the nutrient components of figs based on their cultivars. Korean J Food Preserv, 20, 336-341

21. Kim EA, Mann SY, Kim SI, Lee GY, Hwang DY, Son HJ, Lee CY, Kim DS (2013) Isolation and identification of soycurd forming lactic acid bacteria which produce GABA from kimchi. Korean J Food Preserv, 20, 705-711 